\title{
ŠTUDENTI Z BRATISLAVSKEJ STOLICE NA ZAHRANIČNÝCH UNIVERZITÁCH A VYSOKÝCH ŠKOLÁCH DO ROKU 1918
}

\author{
Szerkesztette Miroslav Kamenický-László Szögi \\ Post Scriptum Kiadó, Pozsony, 2017, 476 lap
}

Az oktatásügy múltjának kutatása, dokumentálása és bemutatása mára a történeti kutatások közkedvelt tárgyává vált Európa-szerte. Rendkívüli népszerűségnek örvendenek az egyetemtörténeti (jubileumi) kiadványok, sorra jönnek létre egyetemtörténeti gyűjtemények és nyílnak kiállítások. Az egyetem- és tudománytörténeti kutatások nem elhanyagolható területe a mindenkori nemzeti értelmiség kialakulásában óriási szerepet játszó egyetemi-főiskolai hallgatóság sokaságának, származási (földrajzi, társadalmi, nemzeti és felekezeti) összetételének és tudományági megoszlásának vizsgálata, valamint peregrinációtörténete, korunk szavával élve: mobilitása.

A Pozsony vármegyéböl származó és a középkortól 1918-ig terjedö idöszakban külföldi egyetemeken és föiskolákon tanulmányokat folytató diákságot egyrészt az egyetemi levéltári kutatások során, másrészt a már korábban kiadott, szakmai körökben jól ismert egyetemtörténeti művek alapján feltáró projekt és az eredményeit dokumentáló kötet létrejöttét is számos hasonló tudományos vállalkozás előzte meg mind Szlovákiában, mind Magyarországon. A legfrissebbek közül is kiemelkedik a pozsonyi Komenský Egyetem Pedagógiai Kara Történelem Tanszékének munkájával megvalósult, a Szlovákiából származó egyetemisták a külföldi egyetemeken és föiskolákon 1945-ig címü pályázat (2013-2015).

Miroslav Kamenický, a most bemutatott kötet szerkesztőpárosának szlovák tagja is több szállal kötődik a pozsonyi Komenský Egyetemhez. Itt szerzett diplomát levéltártörténelem szakon, majd 1995 óta a Pedagógiai Karon a Bölcsészkutatások Intézetében működő Történelem Tanszéken dolgozik. 2004 óta a Szlovák Tudományos Akadémia berkein belül tevékenykedő Szlovák Történelmi Társaság Gazdaság- és Társadalomtörténeti Osztályának elnöke.

Magyarországon, a budapesti Eötvös Loránd Tudományegyetem Levéltárában már harminc éve indult az a kutatási program, melynek célja a történelmi Magyarországról származó és külföldi egyetemeken és akadémiai gimnáziumokban (a kezdetektől 1918-ig) tanulmányokat folytató diákok adatbázisba gyüjtése. A kutatócsoport vezetője, Szögi László a budapesti Eötvös Loránd Tudományegyetem Bölcsészettudományi 
Karán szerzett egyetemi végzettséget. 1995-2013 között az ELTE Egyetemi Könyvtár föigazgatója és a Levéltár igazgatója volt. 2013 óta a Magyar Tudományos Akadémia és az Eötvös Loránd Tudományegyetem által működtetett Egyetemtörténeti Kutatócsoport projektvezetője. Három részlegben: a közép-, az újkori és a XX. századi részlegben 2013 óta folynak a peregrinációkutatások. Monumentális munkájuk során Európa 27 országának 240 egyetemén mintegy 100 ezer egyetemi beiratkozás adatait gyüjtötték össze a középkortól 1918-ig. Ezek között találjuk természetesen a mai Szlovákia területéről származó diákok adatait is. 2012-ben jelent meg az a tanulmányuk, amely a Sáros vármegyéből elszármazott és európai egyetemeken 1387-1918 között tanulmányokat folytató diákokat veszi számba, s amely a jelen monográfiában publikált kutatások módszertani alapjait adta. A magyar partnert öt évvel ezelőtt kereste meg együttműködési szándékával a Komenský Egyetem.

A szlovák-magyar együttmunkálkodás és nemzetközi kutatómunka eredményeként elkészült terjedelmes kiadvány három fő fejezetben (I-III.) jól rendszerezve dolgozza fel az adatokat. I. A történelmi Magyarország megyerendszeréről és Pozsony város iskolatörténetének kezdeteiről szóló rövid áttekintést követően e fejezetben összefoglaló képet kapunk arról, hogy a vizsgált korszakokban mely külföldi egyetemeken milyen létszámban tanultak az egyetemjáró diákok, illetve arról is, hogy ők a tizenkét felvidéki megye melyikéből származtak.

II. Az 1263-1918 közötti külföldi egyetemjárás statisztikai mutatóit tartalmazó fejezet korszakonként (1263-1525 és 1525-1918) és látogatottságuk mértéke alapján rangsorolja az intézményeket. A táblázatok számadataiból kiderül, mindkét vizsgált korszakban (1263-1526 és 1526-1918), és úgy a Pozsony megyéből, mint a Pozsony városából származó diákok körében - minden bizonnyal a földrajzi közelség miatt -, a legnagyobb látogatottságnak Bécs egyetemei (Bécsi Egyetem, kisebb mértékben a bécsi Műegyetem), azonfelül művészeti és katonai akadémiái, valamint a Grazi Egyetem örvendett.

Láthatjuk továbbá, hogyan szaporodtak az európai egyetemek, és hogy növekedett Pozsony városának és Pozsony megye külföldön egyetemre beiratkozott diákjainak a száma az évszázadok során. Az 1263-1525 közötti időszakban a Pozsony megyéből elszármazott 441 diák közül 388-an Bécs egyetemein tanultak, a többiek jellemzően itáliai egyetemek (Bologna, Ferrara, Padova, Nápoly, Róma) előadásait látogatták.

A XIV. században elsősorban annak köszönhetően javultak a diákok külföldi tanulásának a lehetőségei, hogy Közép-Európában három egyetemet is alapítottak: Prága (1348), Krakkó (1364) és Bécs (1365) városában indult felsőfokú oktatás. Ezek mindegyike folyamatosan müködik napjainkban is, nem úgy az 1367-ben I. Nagy Lajos király által Pécsett létrehozott első magyarországi egyetem és a Corvin Mátyás király által 1465-ben alapított pozsonyi Academia Istropolitana.

Az 1526-1918 közötti időszakban a Pozsony megyéből elszármazott és a kötetben felsorolt 6073 diák már több mint háromszáz külföldi felsőfokú iskolán folytatott tanulmányokat beiratkozott hallgatóként. 
III. A diákok 6501 cikkelyt tartalmazó névjegyzékét magában foglaló fejezet négy alfejezete a származási hely szerint rendszerezi az adatokat: i.) A középkori Pozsony város; ii.) Az újkori Pozsony város; iii.) A középkori Pozsony megye; iv.) Az újkori Pozsony megye. Az egyes egyetemek nevei alatt a beiratkozások kronológiai rendjében (a legkorábbitól a legkésőbbiig) találjuk a peregrinusok neveit. Ezek mellett olyan adatok jelennek meg, mint életkor, származási (születési) hely, felekezeti hovatartozás, az apa foglalkozása, az egyetemi beiratkozás dátuma, a szak megnevezése, a tanulmányok befejezésének dátuma, a további egyetemek megnevezése, ahol az illető tanult, végül a forrás megjelölése, amennyiben ez nem az egyetemi matrikula. Olyan kisebb-nagyobb terjedelmű egyetemtörténeti kiadványok ezek, melyek a külföldön járt magyar diákok adatait dolgozzák fel, jellemzően az egyes országok valamennyi egyetemének, ritkábban önállóan az egyes egyetemek tanulmányi anyakönyveit nagyító alá véve.

A névjegyzékben többek között neves magyar történelmi családok leszármazottjainak, a különböző tudományok és művészetek jeles, nemegyszer világhírnévre is szert tett képviselőinek nevei olvashatók. A tanulmányi adatok alkalmas adalékként szolgálhatnak ahhoz, hogy akár az Andrássy, Batthyány, Esterházy, Vattay vagy Zichy család leszármazottjainak élettörténetét és érdemeit eddig nem ismert adatokkal gyarapítsák, illetőleg pontosítsák az életrajzírók. Például egyedül az Esterházy család fó- és mellékágaiból nem kevesebb, mint 15 leszármazott külföldi egyetemi tanulmányainak adatait találjuk a regiszterben. Közülük sokak pályafutása régóta ismert és jól dokumentált (legfóképp gróf galántai Eszterházy Károly váci és egri püspök élete és munkássága). Ugyanakkor vajmi keveset tudunk az 1809-ben a Bécsi Egyetemre beiratkozott (a kötetben 4384-es sorszám alatt bejegyzett) gróf galántai Eszterházy József életpályájáról.

A figyelmes olvasó a magyar művelődés és tudomány olyan kimagasló képviselőinek a nevét is felfedezheti a pozsonyi vagy Pozsony megyei diákok közt, akik egykor a Debreceni Református Kollégiumban végezték középiskolai tanulmányukat: így Szenczi Molnár Albertus (Szenczi Molnár Albert) és Segner Johannes Andreas (Segner János) nevét is.

Pozsony vármegye Szenc településéről származik a magyar protestáns művelődés egyik legjelesebb képviselője, Szenczi Molnár Albert (1574-1634). Ö 1588-tól 1590 nyaráig tanult Debrecenben, a Református Kollégiumban. Ezt követően Európa kilenc egyetemén is gazdagította tudását, ahogy a kutatások kimutatták. Ezek szerint beiratkozott diákja volt a reformáció fellegváraiban (Wittenberg, Heidelberg, Lausanne, Genf, Herborn, Altdorf, Marburg) működő egyetemeknek is.

Segner János (1704-1777) szintén a Debreceni Református Kollégium diákja volt egykoron, majd 1725-ben a Jénai Egyetem medikus hallgatója lett, és 1730-ban avatták itt orvossá.

A Pozsony vármegyéből induló peregrináció történetét bemutató kötet szerteágazó történelmi, helytörténeti, szociológiai és nyelvészeti kutatásokhoz szolgálhat a jövőben adatbázisként vagy ihlethet új kutatási irányokat szerte a világban. Adatai, táblázatai, 
személy- és helynévmutatói, bibliográfiai jegyzéke nagymértékben hozzájárulhat az egyetemjáró diákok nevei mögött rejlő személyek eddig fel nem tárt életútjának, politikai vagy közéleti pályájának, tudományos sikereinek pontosabb megismeréséhez.

Sőt akár új problémákat és kérdéseket is felvethetnek a most közölt adatok. Így például: vajon a Pozsony vármegyei Szentgyörgyön 1832-ben született és később a magyar tudományos életben elsősorban „Kelet-kutató” Vámbéry Árminként számon tartott személy, aki a kötet 5998-as sorszám alatt bejegyzett „Vámbéry (Wamberger) Hermann (Ármin)" diákja, csakugyan beiratkozott-e hatvanévesen, 1892-ben a Londoni Egyetemre? Ahogy ezt a Dublini Egyetem Diplomásai 1895-1931 forrásra hivatkozva olvassuk. Ahogy azt is, hogy két évvel később, 1894-ben a Dublini Egyetem díszdoktorává fogadta Vámbéry Ármint.

A kötet a magyarországi, Kárpát-medencei és európai oktatás- és tudománytörténeti összefüggéseket megjelenítő rendkívül fontos közlemény, így jelentősége - mind tartalmi, mind módszertani szempontból - nemzetközi. Példaértékủ munkaként képezi részét a Nemzetközi Egyetemtörténeti Bizottság által 2012-ben kezdeményezett együttműködésnek, amelynek keretében össze kívánják kapcsolni az egyes országokban már évek óta készülő középkori és újkori hallgatói adatbázisokat.

Fórián Éva 